\title{
BULLETIN
}

OF THE

\section{American Mathematical Society}

\author{
EDITED BY
}

RUDOLPH ERNEST LANGER

DEANE MONTGOMERY
SAUNDERS MACLANE

ELLIS B. STOUFFER

WITH THE ASSISTANCE OF

E. G. BEGLE

IRVING KAPLANSKY

LEO ZIPPIN

\begin{abstract}
R. H. BRUCK
\end{abstract}
E. $\mathbf{R}$ LORCH

R. H. CAMERON

J. C. OXTOBY OTTO SZĀSZ

VOLUME 52, NUMBER 3

MARCH, 1946 


\section{AMERICAN MATHEMATICAL SOCIETY}

Mail Address: Low Memorial Library, 531 West 116th Street, New York 27, N.Y., for the Secretary, Treasurer, Librarian, and Office Manager.

Office: Room 305, Low Memorial Library, 531 West 116th Street, New York 27, N. Y.

President: Professor T. H. Hildebrandt, University of Michigan, Ann Arbor, Mich.

Secretary: Professor J. R. Kline, University of Pennsylvania, Philadelphia 4, Pa.

Associate Secretaries: Professor W. L. Ayres, Purdue University, Lafayette, Ind.; Professor R. H. Bruck, University of Wisconsin, Madison 6, Wis.; Professor T. R. Hollcroft, Wells College, Aurora, N. Y.; Professor A. C. Schaeffer, Stanford University, Stanford University, Calif.

Treasurer: Professor B. P. Gill, College of the City of New York, New York 31, N. Y.

Librarian: Professor Arnold Dresden, Swarthmore College, Swarthmore, Pa.

Office Manager: Miss Evelyn M. Hull, Low Memorial Library, 531 West 116th Street, New York 27, N. Y.

Managing Editor of the Bulletin: Professor Saunders MacLane, 474 Widener, Harvard University, Cambridge 38, Mass.

Managing Editor of the Transactions: Professor A. A. Albert, University of Chicago, Chicago 37, Ill.

Editors of Mathematical Reviews: Professor Otto Neugebauer, Brown University, Providence 12, R. I.; Professor M. H. Stone, Harvard University, Cambridge 38, Mass.; and Professor Oswald Veblen, Institute for Advanced Study, Princeton, N. J.

Chairman, Colloquium Editorial Committee: Professor G. T. Whyburn, University of Virginia, Charlottesville, Va.

Chairman, Mathematical Surveys Editorial Committee: Professor Nelson Dunford, Yale University, New Haven, Conn.

Editors of American Journal of Mathematics: Professor Richard Brauer, University of Toronto, Toronto, Ont., Canada; Professor L. M. Graves, University of Chicago, Chicago 37, Ill.; Professor F. D. Murnaghan, Johns Hopkins University, Baltimore 18, Md.; Professor Hassler Whitney, Harvard University, Cambridge 38, Mass.; and Professor Aurel Wintner, Johns Hopkins University, Baltimore $18, \mathrm{Md}$.

The Bulletin of the American Mathematical Society is published monthly. Price per annual volume, $\$ 9.00$. Subscriptions, orders for back numbers, and inquiries in regard to nondelivery of current numbers should be addressed to the American Mathematical Society, 450 Ahnaip Street, Menasha, Wis., or Low Memorial Library, 531 West 116th Street, New York 27, N. Y.

Entered as second class matter April 24, 1926, at the post office at Menasha. Wis., under the act of August 24, 1912. Acceptance for mailing at the special rate of postage provided for in the act of February 28, 1925, embodied in paragraph 4, section 538, P. L. and R., authorized May 9, 1935.

Copyright, American Mathematical Society, 1946 